\title{
ESTHETIC PERCEPTION OF THE BUCCAL CORRIDOR IN DIFFERENT FACIAL TYPES BY LAYPERSONS OF DIFFERENT AGES
}

\author{
PERCEPÇÃO ESTÉTICA DO CORREDOR BUCAL EM DIFERENTES TIPOS \\ FACIAIS POR LEIGOS DE DIFERENTES IDADES
}

\author{
Rogério LACERDA-SANTOS ${ }^{1}$; Tiago Batista PEREIRA ${ }^{2}$; Matheus Melo PITHON ${ }^{3}$ \\ 1. Professor, Department of Orthodontics, Federal University of Campina Grande, Patos, Paraíba, Brazil. lacerdaorto@ hotmail.com; \\ 2. Postgraduate Program in Dentistry, Federal University of Paraíba - UFPB, João Pessoa, Paraíba, Brazil; 3. Professor, Department of \\ Orthodontics, State University of Southwest Bahia, Jéquie, Bahia, Brazil.
}

\begin{abstract}
The focus of this study was to test the hypothesis that the amount of buccal corridor associated with dolicofacial, mesofacial and brachyfacial facial patterns has no influence on smile evaluations by laypersons of different age groups. A photograph was constructed of a woman displaying a broad smile. Buccal corridors were modified digitally in increments of $5 \%$ and $10 \%$, displaying from $0 \%$ to $30 \%$ buccal corridor compared with the inner commissural width. Using a visual analog scale(VAS), 150 laypersons divided into 3 groups $(n=50)$ of age-ranges from 15-19, 35-44 and 65-74 years of age rated the attractiveness of five smiles with altered buccal corridors. Differences in the median esthetic scores were analyzed using the Kruskal-Wallis test $(P<0.05)$. Laypersons over the age of 65 years made a less critical judgment as regards attractiveness of the smile. In the comparison between groups of individuals of different ageranges for the size of the buccal corridor at $0 \%, 10 \%$ and $15 \%$ there was no significant difference for any of the facial types $(P>0.05)$. There was significant difference between the groups from 15-19 and 65-74 years of age in evaluating the attractiveness of the smile with the size of the buccal corridor at $20 \%$ and $30 \%$ for the $\operatorname{short}(P=0.045$, and $P=0.035)$ and long $(P=0.029$, and $P=0.038)$ facial types, respectively. The hypothesis was rejected. Laypersons over the age of 65 years attributed higher scores. Irrespective of age, laypersons preferred broader smiles with a smaller buccal corridor, with $15 \%$ being the limit between the most and least attractive smile.
\end{abstract}

KEYWORDS: Esthetics. Face. Orthodontics.

\section{INTRODUCTION}

The influence of the smile on facial appearance has become increasingly important in contemporary orthodontics (PAREKH et al., 2007; PITHON et al., 2012). One aspect of smile esthetics has recently received great attention, the spaces of the buccal corridor (IOI et al., 2009). The buccal corridor may be defined as the proportion of the distance between the maxillary canines, and the distance between the corners of the lips in the smile (ZANGE et al., 2011). However, other authors (FRUSH; FISHER, 1958; MOORE et al., 2005) have defined the buccal corridor as being the distance from the most visible posterior teeth in the smile to the inner commissures of the lips.

It has been recognized that laypersons are capable of identifying variations in the buccal corridor in photographs of the face, which influences the manner in which they judge the esthetics of a smile (MOORE et al., 2005; ZANGE et al., 2011). Traditionally, the buccal corridor has been evaluated by means of photographs of the smile, however, the evaluation of the facial image and their types (IOI et al., 2009), such as the dolicofacial and brachyfacial types (Ackerman, 2005; MOORE et al., 2005; ZANGE et al., 2011), together with the mesofacial type may have a greater influence on the macro esthetic final evaluation of the smile by laypersons, leading to more faithful information of attractiveness (MOORE et al., 2005).

However, there is a lack of studies about the influence of variations in the quantity of spaces of the buccal corridor associated with different facial types (ZANGE et al., 2011) in esthetic attractiveness when judged by lay persons of different age-ranges. At present, with the increase in life expectancy and maintenance of the natural teeth, individuals of different ages have sought orthodontic treatment due to concern about smile esthetics (IOI et al., 2009). In this sense, the purpose of this study was to test the hypothesis that the amount of the buccal corridor associated with the dolicofacial, mesofacial and brachyfacial facial patterns has no influence on smile esthetic evaluations of lay persons of different age groups.

\section{MATERIAL AND METHODS}

In order to conduct this study, a front view intraoral photograph of a smiling female patient, aged 32 years, with normal occlusion was used. The photograph was taken with a digital camera (10 
Megapixels, Canon Rebel XTI, Japan), resulting in images in which the whole face could be seen. The real photograph was manipulated with the use of a computer software program, Adobe Photoshop CS3 (Adobe Systems Inc., San Francisco, CA, USA). The changes in the photograph were made in the region of the upper arch of the image with various compositions of buccal corridor, and in the face for the different facial types as dolichofacial (long face), mesofacial (balanced face) and brachyfacial (short face).

Five images of each facial type were obtained from the absence of buccal corridor to growing presence in the manipulated images (Figures 1 to 3 ).
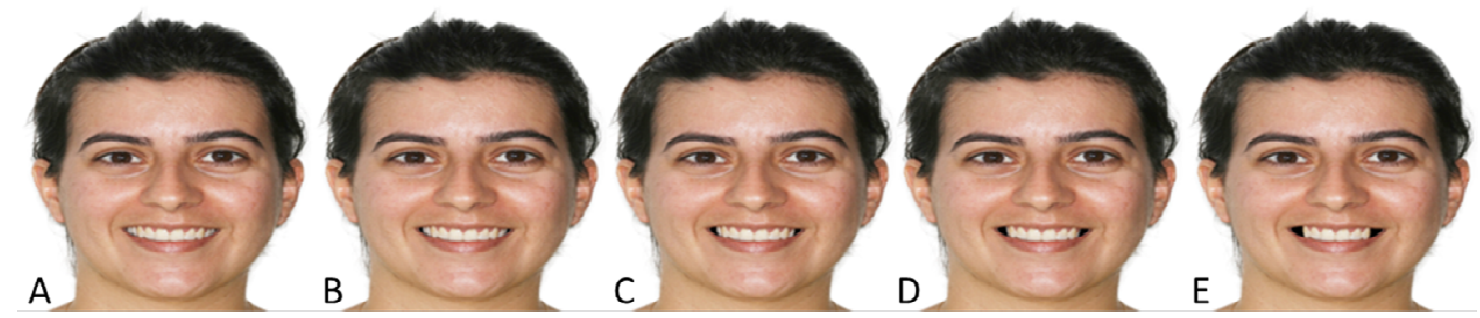

Figure 1. Set of five different full smiles in a subject with a short face. A) narrow, $30 \%$ buccal corridor. B) medium-narrow, $20 \%$ buccal corridor. C) medium, $15 \%$ buccal corridor. D) medium-wide, $10 \%$ buccal corridor. E) wide, 0\% buccal corridor. Source: Pithon et al. (2014a).
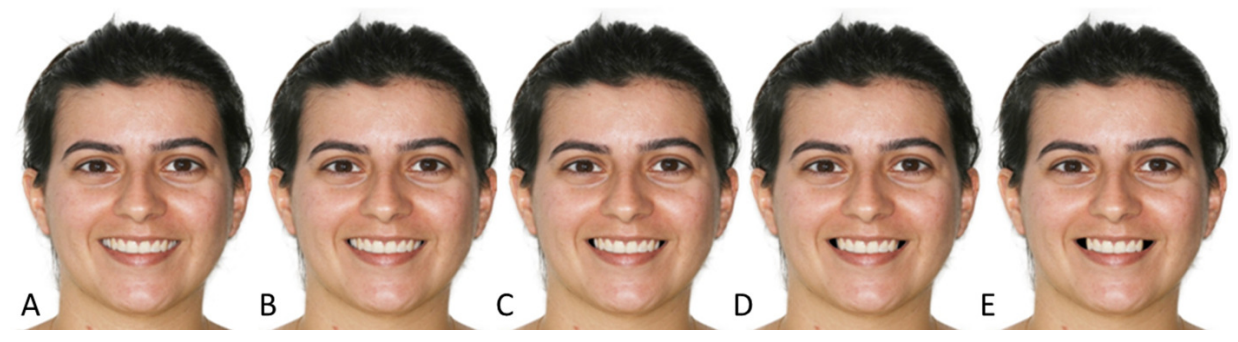

Figure 2. Set of five different full smiles in a subject with a balanced face. A) narrow, $30 \%$ buccal corridor. B) medium-narrow, $20 \%$ buccal corridor. C) medium, $15 \%$ buccal corridor. D) medium-wide, $10 \%$ buccal corridor. E) wide, 0\% buccal corridor. Source: Pithon et al. (2014a).
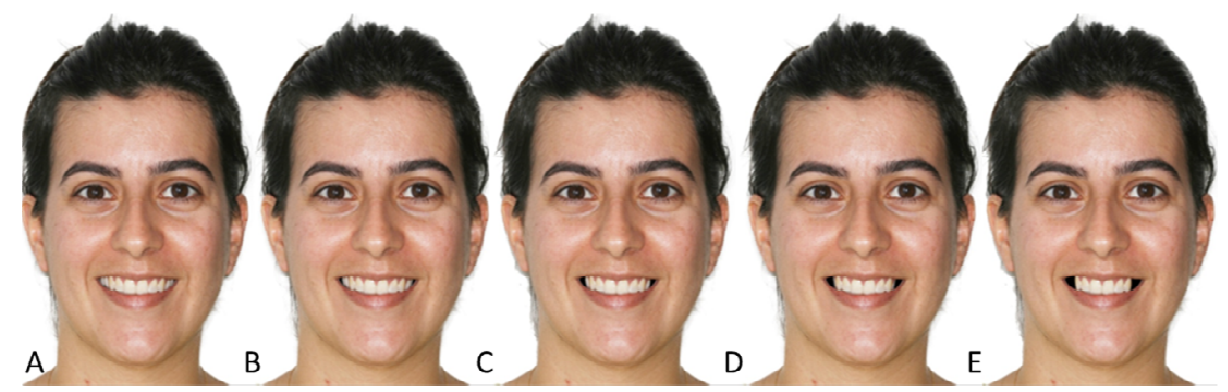

Figure 3. Set of five different full smiles in a subject with a long face. A) narrow, $30 \%$ buccal corridor. B) medium-narrow, $20 \%$ buccal corridor. C) medium, $15 \%$ buccal corridor. D) medium-wide, $10 \%$ buccal corridor. E) wide, 0\% buccal corridor. Source: Pithon et al. (2014a).

The measurement of the buccal corridor was calculated as the percentage of the width between the inner lip commissures. This percentage was the ratio between the measurement of the visible maxillary dentition (A) and width of the inner lip commissures (B), multiplied by 100 . For example, for a corridor calculated at $20 \%$, there would be a visible dentition of $80 \%$, with each side of the corridor accounting for $10 \%$. Five images were produced for each subject, creating a series of five 
different smiles: narrow (30\% buccal corridor), medium-narrow (20\% buccal corridor), medium (15\% buccal corridor), medium-wide (10\% buccal corridor), and wide ( $0 \%$ buccal corridor) (Figures 1 $3)$. In order to conduct the research, 3 groups with 50 individuals in each were selected from among the following age groups: 15-19, 35-44 and 65-74 years (ages pre-established by the World Health Organization - WHO). The images were printed on photographic paper, attached to a questionnaire and distributed among the groups of evaluators.

On the first page all the images were presented together in random sequence, together with the following questions: Can you note differences between the images? Which image do you like most and which do you like least? On a second page, the distribution of the same images was altered. This second page served to evaluate the degree of reliability of the responses given by the evaluators in the first round of evaluation. In the sequence of the research, each image was printed separately on additional pages (so that they could be evaluated individually) together with an attractiveness scale. A visual analogue scale (VAS) with $100 \mathrm{~mm}$ was used for the assessment of attractiveness, on which 0 would represent "hardly attractive", 50 "attractive" and 100 "very attractive". All the evaluators were advised not to compare the images on different sheets. The evaluation time interval for each image was limited to 60 seconds. This experiment was approved by the Ethics Committee on Human Research, CEP/CAAE:10933512.5.0000.8815.

A pilot study had been performed with 10 laypersons to calculate judgment sample size. Considering $10 \mathrm{~mm}$ to be a minimal difference among VAS means, a mean standard deviation error of $10 \mathrm{~mm}$, a bilateral alpha of 0.05 , and a 0.95 power analysis, and a minimum of 32 patients per group was required (BioEstat 5.0, Mamirauá, Belém, Pará, Brazil).

\section{Statistical analysis}

The scores of grades awarded to each photograph were compared by means of the Kruskal-Wallis test followed by Dunn's test. The Wilcoxon test was used to evaluate between groups at different times. The level of significance adopted was 5\% $(\alpha=0.05)$. The data were tabulated and analyzed using the software programs SPSS version 21.0. (IBM Corporation, Armonk, NY, USA).

\section{RESULTS}

The demographic data of the study participants are shown in Table 1. Of the 150 individuals, $54 \%$ were of the female sex.

Table 1. Demographic data of study participants per groups.

\begin{tabular}{lccc}
\hline \multirow{2}{*}{ Characteristics } & \multicolumn{3}{c}{ Age Group (years) } \\
\cline { 2 - 4 } & $\mathbf{1 5 - 1 9}(\mathbf{n}=\mathbf{5 0})$ & $\mathbf{3 5 - 4 4}(\mathbf{n}=\mathbf{5 0})$ & $\mathbf{6 5 - 7 4}(\mathbf{n}=\mathbf{5 0})$ \\
\hline Sex & & & \\
Male & $24(48.0 \%)$ & $23(46.0 \%)$ & $22(44.0 \%)$ \\
Female & $26(52.0 \%)$ & $27(54.0 \%)$ & $28(56.0 \%)$ \\
\hline
\end{tabular}

The Wilcoxon test revealed intra-evaluator agreement on the two different occasions of evaluation (Table 2). In the comparison between the different facial types for each age=range, they were judged to be statistically similar, irrespective of the size of buccal corridor evaluated $(P>0.05)$ (Table 3$)$.

Table 2. Means and standard deviations of grades given by laypersons of different age groups (Opinions) on two separate occasions.

\begin{tabular}{ccccc}
\hline $\begin{array}{c}\text { Age Group } \\
\text { (years) }\end{array}$ & Time & $\begin{array}{c}\text { Mean } \\
\text { Grade }\end{array}$ & $\begin{array}{c}\text { Standard } \\
\text { Deviation }\end{array}$ & P Value* \\
\hline $15-19$ & Before & 41.60 & 12.29 & 0.437 \\
& After & 42.30 & 11.87 & 0.562 \\
\hline $35-44$ & Before & 43.20 & 11.05 & 0.833 \\
& After & 44.10 & 10.06 & \\
\hline $65-74$ & Before & 49.40 & 12.54 & \\
& After & 50.20 & 11.78 & \\
\hline
\end{tabular}

* Wilcoxon's Test $(P<.05)$. 
In the comparison between groups of individuals of different age-ranges for the size of the buccal corridor at $0 \%, 10 \%$ and $15 \%$ there was no significant difference for any of the facial types $(P>0.05)$. However, there was a tendency of the group of individuals in the 65-74 year age group to award higher scores for smile attractiveness to these 3 sizes of buccal corridor when compared with individuals from 15-19 and 35-44 years of age (Table 3).

When considering the buccal corridor sizes of $20 \%$ and $30 \%$, the group of individuals from $15-$
19 awarded lower smile attractiveness scores and the group of individuals of 65-74 years higher scores. There was significant difference between the groups of 15-19 and 65-74 years of age in evaluating the attractiveness of the smile with the size of the buccal corridor at $20 \%$ for the short $(P=0.045)$, and long $(P=0.029)$ facial types. The same judgment was observed in these groups of evaluators for smile attractiveness with the buccal corridor size of $30 \%$ for the short $(P=0.035)$ and long $(P=0.038)$ facial types (Table 3$)$.

Table 3: Means and standard deviations of grades given by laypersons of different age groups.

* Kruskal-Wallis test followed by Dunn's test $(P<.05)$.

\begin{tabular}{|c|c|c|c|c|c|}
\hline \multirow{2}{*}{$\begin{array}{c}\text { Buccal Corridor } \\
\text { Size }\end{array}$} & \multirow[t]{2}{*}{ Facial Type } & \multicolumn{3}{|c|}{ Age Group (years) } & \multirow[t]{2}{*}{$P$-value* } \\
\hline & & 15-19 & $35-44$ & $65-74$ & \\
\hline \multirow{3}{*}{$0 \%$} & Short & $70.40(16.05)$ & $68.20(15.03)$ & $74.80(17.12)$ & 0.481 \\
\hline & balanced & $74.60(16.08)$ & $71.40(15.05)$ & 75.60 (18.07) & 0.645 \\
\hline & Long & $70.60(14.09)$ & $68.60(12.11)$ & $75.80(16.13)$ & 0.469 \\
\hline$P$-value* & & 0.576 & 0.676 & 0.905 & $\begin{array}{l}------- \\
\end{array}$ \\
\hline \multirow{3}{*}{$10 \%$} & Short & $66.20(15.03)$ & $64.80(13.16)$ & $69.40(13.06)$ & 0.593 \\
\hline & balanced & $69.60(13.10)$ & $67.40(14.06)$ & $71.60(13.10)$ & 0.526 \\
\hline & Long & $67.20(16.03)$ & $63.60(14.09)$ & $70.40(14.06)$ & 0.504 \\
\hline$P$-value & & 0.756 & 0.549 & 0.734 & $\begin{array}{l}------- \\
\end{array}$ \\
\hline \multirow{3}{*}{$15 \%$} & Short & $40.20(13.04)$ & $41.40(10.08)$ & $47.80(10.20)$ & 0.471 \\
\hline & balanced & $43.40(11.54)$ & $45.80(11.56)$ & $50.60(12.54)$ & 0.479 \\
\hline & Long & $41.20(11.05)$ & $42.40(10.54)$ & $49.80(12.55)$ & 0.469 \\
\hline$P$-value & & 0.603 & 0.551 & 0.776 & ------- \\
\hline \multirow{3}{*}{$20 \%$} & Short & $21.20(6.05)^{\mathrm{A}}$ & $27.40(5.12)^{\mathrm{AB}}$ & $32.20(5.40)^{\mathrm{B}}$ & 0.045 \\
\hline & balanced & $23.40(6.14)$ & $29.40(6.80)$ & $35.20(7.08)$ & 0.097 \\
\hline & Long & $17.20(4.81)^{\mathrm{A}}$ & $23.20(6.09)^{\mathrm{AB}}$ & $31.60(8.17)^{\mathrm{B}}$ & 0.029 \\
\hline$P$-value & & 0.247 & 0.367 & 0.643 & $\begin{array}{l}------ \\
\end{array}$ \\
\hline \multirow{3}{*}{$30 \%$} & Short & $14.40(4.21)^{\mathrm{A}}$ & $17.20(4.14)^{\mathrm{AB}}$ & $23.20(5.11)^{\mathrm{B}}$ & 0.035 \\
\hline & balanced & $16.40(4.61)$ & $19.60(5.59)$ & $26.20(5.11)$ & 0.053 \\
\hline & Long & $10.20(4.14)^{\mathrm{A}}$ & $14.20(5.11)^{\mathrm{AB}}$ & $20.40(5.59)^{\mathrm{B}}$ & 0.038 \\
\hline$P$-value & & 0.137 & 0.311 & 0.232 & ------- \\
\hline
\end{tabular}

\section{DISCUSSION}

Understanding the attractiveness of the smile and the factors that directly interfere with it, such as the buccal corridor deserves great important, because the majority of lay persons use the smile as a parameter to judge the need for orthodontic treatment or whether the treatment has been successful or not (PAREKH et al., 2007). In the present study the real influence of the buccal corridor on the esthetics of the smile was investigated.

The majority of the studies in this area have used images of the region of the mouth (JOHNSON; SMITH, 1995; KIM; GIANELLY, 2003; RODEN-
JOHNSON et al., 2005; PAREKH et al., 2006; MAULIK; NANDA, 2007; PAREKH et al., 2007), and little is known about the attractiveness of the smile associated with the presence of the buccal corridor, comparing the judgments of laypersons of different age-ranges. Moreover, studies involving the attractiveness of the smile must take into consideration the different facial types (ACKERMAN, 2005; ZANGE et al., 2011), because laypersons may evaluate the buccal corridor in a different manner when they see the persons entire face, instead of seeing only the smile and region of the mouth (MOORE et al., 2005; VALIATHAN; GANDHI, 2005). 
Studies (IOI et al., 2009; ZANGE et al., 2011) have demonstrated the judgments and comparison of smile attractiveness among young laypersons and orthodontists with regard to the buccal corridor, but they have not considered the variability in the age-range between lay persons in the population. Individuals over the age of 65 years have increasingly sought orthodontic treatment, due to the increase in life expectancy at present, and may show different judgments when considering younger age-ranges such as: 15-19 and 35-44 years, which justifies the present study.

The use of the VAS scale in this study (KOKICH et al., 1999; RODEN-JOHNSON et al., 2005; GRACCO et al., 2006; KOKICH et al., 2006; PAREKH et al., 2006; MARTIN et al., 2007; PAREKH et al., 2007; KRISHNAN et al., 2008; IOI et al., 2009; ZANGE et al., 2011), Adobe Photoshop to manipulate images (KOKICH et al., 1999; MOORE et al., 2005; RODEN-JOHNSON et al., 2005; KOKICH et al., 2006; PAREKH et al., 2006; PAREKH et al., 2007; ZANGE et al., 2011) and time of exposure and evaluation of the images that have been studied previously (PHILLIPS et al., 1992; MOORE et al., 2005; ZANGE et al., 2011).

In this study, it could be observed that the judgment of smile attractiveness diminished inversely proportional to the size of the buccal corridor evaluated, irrespectively of the age-range of the evaluators. Thus, the buccal corridor at $0 \%$ was considered the best for the three facial types, followed by $10 \%, 15 \%, 20 \%$, with the least attractive being the one at $30 \%$. A similar disposition has been found by other authors when they analyzed studies conducted between laypersons and orthodontists (PHILLIPS et al., 1992; RODENJOHNSON et al., 2005; KOKICH et al., 2006; IOI et al., 2009; ZANGE et al., 2011).

Although there was a tendency of the group of individuals in the 65-74 year age group to award higher scores for smile attractiveness to the buccal corridor of $0 \%, 10 \%$ and $15 \%$ when compared with individuals from 15-19 and 35-44 years of age, this was not significant. These findings corroborate those found by other authors (ZANGE et al., 2011) who showed that laypersons do not observe significant differences between the short and long facial types for a buccal corridor of $2 \%$ and $10 \%$.

If it is expected that unpleasant smiles are those with esthetic scores that range from 0 to 50 and that pleasant smiles are those with scores from 51 to 100 , the laypersons of all age-ranges considered the smiles with buccal corridors of less than $15 \%$ as pleasant and smiles with buccal corridors of over $15 \%$ as being unpleasant. This corroborates the findings of studies (MOORE et al., 2005; PAREKH et al., 2006; MARTIN et al., 2007; IOI et al., 2009; ZANGE et al., 2011) that demonstrated that a broader smile was judged by laypersons as being more attractive than a narrow smile, and is in disagreement with studies (HULSEY, 1970; RODEN-JOHNSON et al., 2005; RITTER et al., 2006) that reported that the buccal corridor space was not a critical problem for the esthetic evaluation of the smile.

In the judgment of the buccal corridor at $20 \%$ and $30 \%$, the group of individuals from 15-19 awarded lower smile attractiveness scores and the group of individuals of 65-74 years higher scores. There was significant difference between the groups of 15-19 and 65-74 years of age in evaluating the attractiveness of the smile with the size of the buccal corridor at $20 \%$ and $30 \%$ for the short and long facial types. This shows that elderly laypersons made less critical judgments of smile attractiveness in comparison with youngsters, specifically as regards short and long facial types.

By age-range, youngsters, adults and elderly laypersons did not differ significantly as regards esthetic attractiveness of the smile by the variations in facial type for each buccal corridor size. Whereas, among the age-ranges, the mesofacial facial type was the only one the individuals of all age-ranges judged to be statistically similar for all the variations in buccal corridor size. This suggests that facial balance plays an important role and favors the judgment of smile attractiveness, irrespective of the evaluator's age.

The less critical evaluation observed by lay persons in the age-range of 65-74 years did not mean less concern about smile esthetics, but suggests that there was a more overall view of the face and less specific of buccal corridor for these individuals, the opposite could have been considered by the young laypersons.

It could be observed that the layperson evaluators were capable of perceiving variations in the buccal corridor, as has been seen in other experiments (MOORE et al., 2005; IOI et al., 2009; ZANGE et al., 2011). In the present study, these variations began to become significant between the different age-ranges as from the buccal corridor of $20 \%$. A small change in the spaces of the buccal corridor could have a relevant influence on the perception of smile esthetics. The results suggest that the size of $15 \%$ appears to be the limit between the most and least attractive smile when evaluating the buccal corridor. This information becomes an important tool in the day-to-day of orthodontist, as it will allow a more coherent decision on the necessity 
of treatment of buccal corridor along with the patient's complaint. In addition to considering the possible results and their impact on the final aesthetic.

In this sense, one must consider that the original shape of each patient's dental arch must be respected during and after orthodontic treatment (PITHON et al., 2014b). A correct diagnosis and planning, bearing in mind the dental arch and bony base that supports it may direct treatments that could minimize the effects of extensive buccal corridors (IOI et al., 2009). The indication of orthopedic or surgical expansion of the maxilla with the sole purpose of reducing the buccal corridor (ZANGE et al., 2011) could minimize this esthetic effect in younger patients, who were more critical when evaluating the presence of the buccal corridor. On the other hand, in elderly patients, this therapy must be considered with caution, since this characteristic of the smile had less influence for these individuals.

\section{CONCLUSIONS}

Significant difference in smile attractiveness occurred among young laypersons between 15-19 years of age, and laypersons over the age of 65 years, with the buccal corridor size of $20 \%$ and $30 \%$ for the short and long facial types, with the short facial pattern receiving better scores.

Laypersons over the age of 65 years made a less critical judgment of smile attractiveness, with the buccal corridor size of $15 \%$ being considered the limit between the most and the least attractive smile.

RESUMO: O foco deste estudo foi testar a hipótese que a quantidade de corredor bucal associada aos padrões faciais dolicofacial, mesofacial e braquifacial não tem qualquer influência sobre as avaliações do sorriso de leigos de diferentes faixas etárias. Uma fotografia de uma mulher exibindo um amplo sorriso foi construída. Corredores bucais foram modificados digitalmente em incrementos de $5 \%$ e $10 \%$, de $0 \%$ a $30 \%$ de corredor bucal em comparação com a largura interna das comissuras. Utilizando uma escala analógica visual (VAS), 150 indivíduos leigos divididos em 3 grupos $(\mathrm{n}=50)$ de faixas etárias de 15-19, 35-44 e 65-74 de idade avaliaram a atratividade de cinco sorrisos com corredores bucais alterados. Diferenças nas pontuações estéticas medianas foram analisadas utilizando o teste de Kruskal-Wallis $(P$ $<0,05)$. Indivíduos leigos acima de 65 anos fizeram um julgamento menos critico quanto à atratividade do sorriso. Na comparação entre grupos de indivíduos de diferentes faixas etárias para o tamanho do corredor bucal em 0\%, 10\% e 15\% não houve diferença significante para nenhum dos tipos faciais $(P>0.05)$. Houve diferença significante entre os grupos de 15-19 e 65-74 anos na avaliação da atratividade do sorriso com tamanho do corredor bucal de $20 \%$ e $30 \%$ para os tipos faciais, curto $(P=0.045$, e $P=0.035)$ e longo $(P=0.029$, e $P=0.038)$, respectivamente. A hipótese foi rejeitada. Leigos acima de 65 deram as maiores pontuações. Independentemente da idade, leigos preferiram sorrisos mais largos com menor corredor bucal, sendo $15 \%$ o limite entre o sorriso mais e menos atraente.

PALAVRAS-CHAVES: Estética. Face. Ortodontia.

\section{REFERENCES}

ACKERMAN, M. B. Buccal smile corridors. Am. J. Orthod. Dentofacial Orthop. St. Louis, v. 127, n. 5, p.528-9, May. 2005.

FRUSH, J. P.; FISHER, R. D. The dynesthetic interpretation of the dentogenic concept. J. Pros. Dent. Augusta, v. 8, n. 4, p.558-581, July. 1958.

GRACCO, A.; COZZANI, M.; D'ELIA, L.; MANFRINI, M.; PEVERADA, C.; SICILIANI, G. The smile buccal corridors: aesthetic value for dentists and laypersons. Prog. Orthod. Heidelberg, v. 7, n. 1, p.56-65, Jan. 2006.

HULSEY, C. M. An esthetic evaluation of lip-teeth relationships present in the smile. Am. J. Orthod. Dentofacial Orthop. St. Louis, v. 57, n.2, p.132-144, Feb. 1970. http://dx.doi.org/10.1016/00029416(70)90260-5

IOI, H.; NAKATA, S.; COUNTS, A. L. Effects of buccal corridors on smile esthetics in Japanese. Angle Orthod. Appleton, v. 79, n. 4, p.628-633, Jul. 2009. http://dx.doi.org/10.2319/080708-410.1 
JOHNSON, D. K.; SMITH, R. J. Smile esthetics after orthodontic treatment with and without extraction of four first premolars. Am. J. Orthod. Dentofacial Orthop. St. Louis, v. 108, n. 2, p.162-167, Aug. 1995. http://dx.doi.org/10.1016/S0889-5406(95)70079-X

KIM, E.; GIANELLY, A. A. Extraction vs nonextraction: arch widths and smile esthetics. Angle Orthod. Appleton, v. 73, n. 4, p.354-358, Aug. 2003.

KOKICH, V. O. JR.; KIYAK, H. A.; SHAPIRO, P. A. Comparing the perception of dentists and lay people to altered dental esthetics. J. Esthet. Dent. Berlin, v. 11, n. 6, p.311-324, Jun. 1999. http://dx.doi.org/10.1111/j.1708-8240.1999.tb00414.x

KOKICH, V. O.; KOKICH, V. G.; KIYAK, H. A. Perceptions of dental professionals and laypersons to altered dental esthetics: asymmetric and symmetric situations. Am. J. Orthod. Dentofacial Orthop. St. Louis, v. 130, n. 2, p.141-151, Aug. 2006. http://dx.doi.org/10.1016/j.ajodo.2006.04.017

KRISHNAN, V.; DANIEL, S. T.; LAZAR, D.; ASOK, A. Characterization of posed smile by using visual analog scale, smile arc, buccal corridor measures, and modified smile index. Am. J. Orthod. Dentofacial Orthop. St. Louis, v. 133, n. 4, p.515-523, Apr. 2008. http://dx.doi.org/10.1016/j.ajodo.2006.04.046

MARTIN, A. J.; BUSCHANG, P. H.; BOLEY, J. C.; TAYLOR, R. W.; MCKINNEY, T. W. The impact of buccal corridors on smile attractiveness. Eur. J. Orthod. Oxford, v. 29, n. 5, p.530-537, Oct. 2007. http://dx.doi.org/10.1093/ejo/cjm063

MAULIK, C.; NANDA, R. Dynamic smile analysis in young adults. Am. J. Orthod. Dentofacial Orthop. St. Louis, v. 132, n. 3, p.307-315, Sep. 2007. http://dx.doi.org/10.1016/j.ajodo.2005.11.037

MOORE, T.; SOUTHARD, K. A.; CASKO, J. S.; QIAN, F.; SOUTHARD, T. E. Buccal corridors and smile esthetics. Am. J. Orthod. Dentofacial Orthop. St. Louis, v. 127, n. 2, p.208-213, Feb. 2005.

http://dx.doi.org/10.1016/j.ajodo.2003.11.027

PAREKH, S.; FIELDS, H. W.; BECK, F. M.; ROSENSTIEL, S. F. The acceptability of variations in smile arc and buccal corridor space. Orthod. Craniofac. Res. Malden, v. 10, n. 1, p.15-21, Feb. 2007.

http://dx.doi.org/10.1111/j.1601-6343.2007.00378.x

PAREKH, S. M.; FIELDS, H. W.; BECK, M.; ROSENSTIEL, S. Attractiveness of variations in the smile arc and buccal corridor space as judged by orthodontists and laymen. Angle Orthod. Appleton, v. 76, n. 4, p.557563, Jul. 2006.

PHILLIPS, C.; TRENTINI, C. J.; DOUVARTZIDIS, N. The effect of treatment on facial attractiveness. J. Oral Maxillofac. Surg. Philadelphia, v. 50, n. 6, p.590-594, Jun. 1992. http://dx.doi.org/10.1016/02782391(92)90439-7

PITHON, M. M.; MATA, K. R.; ROCHA, K. S.; COSTA, B. N.; NEVES, F.; BARBOSA, G. C.; et al. Perceptions of brachyfacial, mesofacial and dolichofacial individuals with regard to the buccal corridor in different facial types. J. Appl. Oral Sci. Bauru, v.22, n.5, p.382-9, Sep-Oct. 2014a.

http://dx.doi.org/10.1590/1678-775720140003

PITHON, M. M.; SANTOS, A. M.; COUTO, F. S.; DA SILVA COQUEIRO, R.; DE FREITAS, L. M.; DE SOUZA, R. A.; et al. Perception of the esthetic impact of mandibular incisor extraction treatment on laypersons, dental professionals, and dental students. Angle Orthod. Appleton, v. 82, n. 4, p.732-738, Jul. 2012. http://dx.doi.org/10.2319/081611-521.1

PITHON, M. M.; SANTOS, R. L.; SAMPAIO, G. A. M.; MENESES, I. H. C.; COQUEIRO, R. S. Anteroposterior and Vertical Changes in Skeletal Class II Patients Treated With Modified Thurow Appliance. Braz. Dent. J. Ribeirão Preto, v. 25, n. 2, p.170-174, Mar. 2014 b. 
RITTER, D. E.; GANDINI, L. G.; PINTO, A. S.; LOCKS, A. Esthetic influence of negative space in the buccal corridor during smiling. Angle Orthod. Appleton, v. 76, n. 2, p.198-203, Mar. 2006.

RODEN-JOHNSON, D.; GALLERANO, R.; ENGLISH, J. The effects of buccal corridor spaces and arch form on smile esthetics. Am. J. Orthod. Dentofacial Orthop. St. Louis, v. 127, n. 3, p.343-350, Mar. 2005. http://dx.doi.org/10.1016/j.ajodo.2004.02.013

VALIATHAN, A.; GANDHI, S. Buccal corridor spaces, arch form, and smile esthetics. Am. J. Orthod. Dentofacial Orthop. St. Louis, v. 128, n. 5, p.557, Nov. 2005. http://dx.doi.org/10.1016/j.ajodo.2005.09.011

ZANGE, S. E.; RAMOS, A. L.; CUOGHI, O. A.; DE MENDONCA, M. R.; SUGUINO, R. Perceptions of laypersons and orthodontists regarding the buccal corridor in long- and short-face individuals. Angle Orthod. Appleton, v. 81, n. 1, p.86-90, Jan. 2011. http://dx.doi.org/10.2319/031210-145.1 